University of Nebraska - Lincoln

DigitalCommons@University of Nebraska - Lincoln

USDA National Wildlife Research Center - Staff Publications
U.S. Department of Agriculture: Animal and Plant Health Inspection Service

2018

\title{
Conclusions, Challenges, and Research Needs
}

\author{
Gary W. Witmer \\ USDA-APHIS-Wildlife Services, gary.w.witmer@usda.gov \\ William C. Pitt \\ Smithsonian Institution \\ James C. Beasley \\ University of Georgia, beasley@srel.uga.edu
}

Follow this and additional works at: https://digitalcommons.unl.edu/icwdm_usdanwrc

Part of the Life Sciences Commons

Witmer, Gary W.; Pitt, William C.; and Beasley, James C., "Conclusions, Challenges, and Research Needs" (2018). USDA National Wildlife Research Center - Staff Publications. 2018.

https://digitalcommons.unl.edu/icwdm_usdanwrc/2018

This Article is brought to you for free and open access by the U.S. Department of Agriculture: Animal and Plant Health Inspection Service at DigitalCommons@University of Nebraska - Lincoln. It has been accepted for inclusion in USDA National Wildlife Research Center - Staff Publications by an authorized administrator of DigitalCommons@University of Nebraska - Lincoln. 


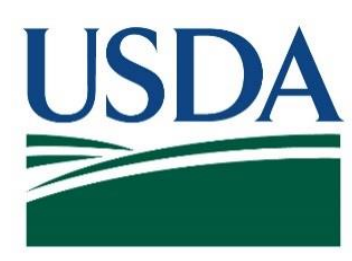

U.S. Department of Agriculture

U.S. Government Publication

Animal and Plant Health Inspection Service

Wildlife Services

Witmer, G.W., W.C. Pitt, and J.C. Beasley. 2018. Conclusions, challenges, and research needs. pgs. 285-388. In: W.C. Pitt, J.C. Beasley, and G.W Witmer, editors. Ecology and Management of terrestrial vertebrate invasive species in the United States. CRC Press, Boca Raton, FL. 403 pp.

Gary W. Witmer, USDA APHIS NWRC, Fort Collins, Colorado

William C. Pitt, Smithsonian Institution

James C. Beasley, University of Georgia 


\title{
18 Conclusions, Challenges, and Research Needs
}

\author{
Gary W. Witmer, William C. Pitt, \\ and James C. Beasley
}

\section{CONTENTS}

References

At least 392 species of introduced vertebrate species (excluding fish) occur in the United States and its territories (Witmer and Fuller 2011). Many of these species can be truly considered "invasive," causing various types of economic, social, and ecological harm. In this book, we have presented examples of many invasive vertebrates in the United States, the impacts they cause, and the methods used to control or eradicate them in various parts of the country.

While progress has been and is being made in the management of invasive vertebrates in the United States, there are still many challenges and issues to resolve (Pimentel et al. 2005; National Invasive Species Council 2008), many of which stem from a lack of sufficient funding for public education, prevention, control, and eradiation of invasive vertebrates. Whereas the majority of attention and funding for invasive species in the United States has focused on plants, insects, and pathogens (Pimentel et al. 2005; Pimentel 2011), relatively little effort and few resources have been directed to vertebrate control, with the notable exceptions of brown tree snakes in Guam and wild pigs across several states. Nonetheless, successful eradications of some invasive species have occurred on a handful of islands; however, for mainland areas, the focus continues to be on long-term control.

Public perception also has hindered efforts to manage or eradicate vertebrate species in the United States, as it has elsewhere in the world (National Invasive Species Council 2008). Knowledge of invasive species and the harm they can cause is relatively limited among the general public unless they are personally impacted (Conover 2002; National Invasive Species Council 2008). Furthermore, many members of the public do not readily distinguish between native and nonnative species: as long as an animal is charismatic and not threatening people or causing undue harm, the public tends to view invasive species equally to native animals (Wittenberg and Cock 2001; Witmer and Fuller 2011). In most cases, the ultimate goal in invasive species control is the eradication of all individuals in a given area; however, much of the public has a strong dislike for the killing of animals (Conover 2002). Certain species such as feral cats, feral dogs, feral horses, and introduced primates are particularly sensitive species to control via lethal means. Furthermore, much of the public has a 
strong fear and distrust of chemicals, and toxicants in particular. Hence, the management of invasive vertebrates, like all wildlife, is being conducted in an increasingly complex arena (Conover 2002; Fall and Jackson 2002).

Exotic pets are very popular with a sizable portion of the public, and thus the pet industry is a major pathway for the introduction of vertebrates into the United States (Kraus 2003; Jenkins 2007). Very few vertebrate species are prohibited from entry into the United States, with a prevailing attitude of "innocent until proven guilty" or a "gray" list approach to species imports (Witmer and Lewis 2001; Pitt and Witmer 2007). However, the development of a more inclusive prohibited species or "black list" approach is needed (Witmer and Lewis 2001; Fowler et al. 2007; Pitt and Witmer 2007). Only after it is determined that a species will not harm the environment, agriculture, or human resources should it be determined safe or added to a "white" list. Such shifts in policy will require greater cooperation, enforcement, and regulation of the pet industry. However, the pet industry is a well-organized, large, and influential industry in the United States, and thus future shifts in policy of this nature will undoubtedly be challenging (Ginsburg 2004).

Once invasive species become established, access to all relevant land and properties is essential for the implementation of successful management and eradication campaigns. However, invasive species mangers often face the situation where access to a wide array of jurisdictions and ownerships is needed. Getting permission to implement control in all these areas rarely occurs and can prevent the success of even a well-planned, well-funded eradication effort. Furthermore, land management mandates and regulations of federal and state agencies vary considerably. This affects the types of management activities (burning, chemical use), vehicles, and tools (leg-hold traps, firearms, toxicants) that can be used on certain properties. Some laws actually protect invasive vertebrate species, such as the Wild Horse and Burro Act and the Migratory Bird Treaty Act. The latter was amended to exclude some nonnative bird species in the United States, such as the mute swan. Finally, there tends to be inadequate coordination and cooperation among invasive species managers across jurisdictions and agencies of all levels of government in the United States. One of the goals of the National Invasive Species Management Plan (National Invasive Species Council 2008) is to enhance interagency coordination of invasive species management. Once established, eradication of an invasive vertebrate species is a complex challenge that in many cases can be difficult to attain. Careful planning is needed, along with adequate resources, public and agency buy-in, highly trained and motivated personnel, contingency plans, and a sustained effort (Broome 2005). Each situation is unique in one or more ways; hence, a cookbook approach cannot be used, even within management efforts for the same species in different areas (Broome 2005).

With the possible exception of rodents and ungulates, the methods and strategies used for management - and especially eradication - of invasive vertebrates need improvement (Wittenberg and Cock 2001; Witmer and Fuller 2011). Much research needs to be conducted to improve detection and eradication methods. Attractants are needed to draw individuals to traps, bait stations, and detection stations. Method improvements are needed to ensure effective and safe delivery of toxicants, vaccines, and fertility control agents. Trained, rapid response teams and early detection systems 
are needed for many more invasive species. Accessible databases on potential invasive species are needed to summarize species identification, biology, ecology, and effective detection and management methods to identify future hazards. The databases should also identify expertise and literature that can be consulted. Although a variety of databases and websites exist (Sellers et al. 2005), it would be very useful if these could be centralized and standardized (Sellers et al. 2004). Finally, risk assessments are needed to determine on which species effort and resources should be focused to be most cost effective (Hayes 2003).

One can surmise that invasive vertebrate species will continue to challenge resource managers, ecologists, and biologists for a long time to come. It also is likely the list of invasive vertebrate species in the United States will continue to grow, but hopefully, some species will also be removed from the list through implementation of successful management regimes. In the United States, there have been some successes with invasive species management and eradications, especially on islands, but also within some areas of the mainland. As a result of this, along with collaborations with international colleagues and a growing interest and involvement by the public and agencies, we are becoming more knowledgeable and proactive in responding to invasive vertebrate species. However, challenges associated with invasive species management are extensive, and undoubtedly efforts to combat their establishment and spread will continue for the foreseeable future.

\section{REFERENCES}

Broome K. 2005. Rat eradication: How to get it right without a recipe. Proceedings of the Australasian Vertebrate Pest Conference 13:152-157.

Conover M. 2002. Resolving Human-Wildlife Conflicts. Boca Raton, FL: CRC Press.

Fall, M. and Jackson, W. 2002. The tools and techniques of wildlife damage management. International Biodeterioration and Biodegradation 49:87-91.

Fowler A, Lodge D, and Hsia J. 2007. Failure of the Lacey Act to protect US ecosystems against animal invasions. Frontiers in Ecology and the Environment 5:353-359.

Ginsburg J. 2004. Dinner, pets, and plagues by the bucketful. The Scientist 18:28-29.

Hayes K. 2003. Biosecurity and the role of risk assessment. In: Ruiz G, Carlton J, eds. Invasive Species: Vectors and Management Strategies. Washington, DC: Island Press, pp. 382-414.

Jenkins P. 2007. Broken screens: The Regulation of Live Animal Imports in the United States. Washington, DC: Defenders of Wildlife.

Kraus F. 2003. Invasion pathways for terrestrial vertebrates. In: Ruiz G, Carlton J, eds. Invasive Species: Vectors and Management Strategies. Washington, DC: Island Press, pp. 68-92.

National Invasive Species Council. 2008. 2008-2012 National Invasive Species Management Plan. Washington, DC: National Invasive Species Council.

Pimentel D. 2011. Biological invasions: Economic and Environmental Costs of Alien Plant, Animal, and Microbe Species. 2nd Ed. Boca Raton, FL: CRC Press.

Pimentel D, Zuniga R, and Morrison D. 2005. Update on the environmental and economic costs associated with alien-invasive species in the United States. Ecological Economics 52:273-288.

Pitt W. and Witmer G. 2007. Invasive predators: A synthesis of the past, present, and future. In: Elewa A, ed. Predation in Organisms: A Distinct Phenomenon. Heidelberg, Germany: Spring-Verlag, pp. 265-293. 
Sellers E, Muir R, and Simpson A. 2004. Summary Report on the Experts Meeting on Implementation of a Global Invasive Species Information Network. Oak Ridge, Tennessee: National Biological Information Infrastructure, Information International Associates, Inc.

Sellers E, Simpson A, and Curd-Hetrick S. 2005. List of Invasive Alien Species (IAS) Online Databases and Data Bases Containing IAS Information. Oak Ridge, TN: National Biological Information Infrastructure, Information International Associates, Inc.

Witmer, GW. and Fuller PL. 2011. Vertebrate species introductions in the United States and its territories. Current Zoology 57:559-567.

Witmer G. and Lewis J. 2001. Introduced wildlife in Oregon and Washington. In: Johnson D, O'Neil T, ed. Wildlife-Habitat Relationships in Oregon and Washington. Corvallis, OR: Oregon State University Press, pp. 423-443.

Wittenberg R. and Cock M. 2001. Invasive Alien Species: A Toolkit of Best Prevention and Management Practices. Wallingford, United Kingdom: CAB International. 